Journal of Animal and Veterinary Advances 9 (18): 2346-2350, 2010

ISSN: $1680-5593$

(C) Medwell Journals, 2010

\title{
Effect of Single Nucleotide Polymorphism of IRF1 Gene on Cytokine Traits in Three Pig Breeds
}

\author{
${ }^{1}$ Y. Liu, ${ }^{1}$ X. Lu, ${ }^{1}$ Y.R. Luo, ${ }^{1}$ J.P. Zhou, ${ }^{1} X$ X.Y. Liu, ${ }^{1}$ Q. Zhang and ${ }^{2} Z$.J. Yin \\ ${ }^{1}$ Key Laboratory of Animal Genetics and Breeding of the Ministry of Agriculture, \\ College of Animal Science and Technology, \\ China Agricultural University, Beijing 100193, P.R. China, \\ ${ }^{2}$ College of Animal Science and Technology, \\ Anhui Agricultural University, Hefei 230036, P.R. China
}

\begin{abstract}
In this study, IRF1 gene was chosen as a candidate gene to evaluate its effect on porcine cytokine traits in serum. A SNP in exon2 was demonstrated by sequencing and PCR-RFLP analysis. Cytokine traits include IFN- $\gamma$ and IL 10 concentrations in serum were measured when the pigs were at 20 and 35 days of age, respectively. The further association analysis between SNP genotype and cytokine traits were conducted in three pig breeds including Large White, Landraces and Songliao Black pig, one Chinese indigenous breed. The results indicated that the SNP of IRF1 gene had highly significant effect on level of IFN- $\gamma$ (day 20; day 35) in serum ( $p=0.0001 ; p=0.0001)$ and ratio of IFN- $\gamma$ to IL10 (day 35) in serum $(p=0.0083)$. The study suggested that the IRF1 gene could be regarded as a molecular marker gene for genetic selection of cytokine traits in the further disease resistance breeding.
\end{abstract}

Key words: Pig, IRF1 gene, polymorphism, cytokines, PCR-RFLP, association analysis

\section{INTRODUCTION}

Interferon Regulatory Factors (IRFs) belong to a family of transcription involved in interferon-inducible genes regulation, viral response, cytokine signaling, cell growth regulation and hematopoietic development (Taniguchi et al., 1995; Nguyen et al., 1997).

IRFs are also essential regulators for the activation of immune cells with the discovery of Pattern Recognition Receptors (PRRs) which function is like a platform that links innate and adaptive immune response (Akira et al., 2006).

Interferon Regulatory Factor 1 (IRF1) is first identified member of the family and shown to bind enhancer elements in the promoter of the gene that encodes IFN- $\gamma$ which is important about viral infection (Miyamoto et al., 1988). IRF1 plays a highly complex role in Th-cell differentiation and affects the expression of many genes, but the overall effect is vigorous promotion after a Th-1 response and influences Th1/Th2 cytokine balance (Lohoff and Mak, 2005).

Cytokines are important mediators of the immune responses. The levels of cytokines in serum such as
Interferon-gamma ( $\mathrm{FN}-\boldsymbol{\gamma})$ and Interleukin 10 (ㄴ-10), vary with organism's status of health. IFN- $\gamma$ is critical for innate and adaptive immunity against viral and intracellular bacterial infections and for tumor control (Schoenborn and Wilson, 2007). IL-10 has pleiotropic effects in immunoregulation and inflammation. It downregulates the expression of Thl cytokines, $\mathrm{MHC}$ class II antigens and costimulatory molecules on macrophages (Redpath et al., 1999).

Differences in levels of these cytokines and their ratios in serum among individuals under same conditions provide evidence of genetic control on these traits. Identification of the genes and their potential functional mutation on these cytokine variants may help to improve immune capacity in pigs.

Considering its potent effects on immune response and cytokines signaling of IRF1 gene, we investigated the polymorphism of the porcine IRF1 gene and then the association between each genotype and cytokines level (IFN- $\gamma, \mathrm{IL}-10, \mathrm{IFN}-\gamma / \mathbb{L}-10)$ in serum was analyzed to evaluate the possible effect of the IRF1 gene in three pig breeds including Large White Landrace and Songliao Black pig, one Chinese indigenous breed.

Corresponding Author: Yin Zongjun, Department of Animal Science, College of Animal Science and Technology, Anhui Agricultural University, Hefei 230036, P.R. China 


\section{MATERIALS AND METHODS}

Animals and sampling: The animals consisted of 284 piglets distributed in 3 pig breeds including Big White pig (148), Landrace (65) and Songliao Black pig (71). All pigs were raised under standard indoor conditions at the experimental farm of the Institute of Animal Sciences, Chinese Academy of Agricultural Sciences, Beijing, China.

All pigs were vaccinated with live (CSF) vaccine at 21 days of age. The first blood samples were collected from each piglet one day before the vaccination (day 20) and 2 weeks after the vaccination, the second blood samples were collected (day 35). All blood samples were directly injected into vacuette ${ }^{\circledR}$ Serum Clot Activator tubes. Ear tissue samples of all pigs were also collected for DNA extract.

Measurement of cytokines level in serum: Cytokines including IFN- $\gamma$ and $\mathrm{IL}-10$ concentrations in each serum sample were measured using a commercial ELISA kit (Biosource, Carlsbad, California) according to the manufacturer's instructions. All samples were arranged randomly in each plate and a standard curve was fitted for each plate and used to calculate IFN- $\gamma$ and $\mathbb{L}-10$ concentrations in each serum sample.

Polymorphism detection and PCR-RFLP: Genomic DNA was isolated from the ear tissue sample using phenol/chloroform extraction and ethanol precipitation (Sambrook et al., 1989). Base on the porcine IRF1 genomic DNA sequence (GenBank accession number: GU201905), seven specific primers which spanned ten exons region of the IRF1 gene were designed by software Oligo 6.0 (Table 1).

The PCR was carried out in a total volume of $25 \mu \mathrm{L}$ including 80-100 ng of template DNA, $10 \mathrm{pmol}$ of each primer, $250 \mu \mathrm{M}$ dNTPs, $2.5 \mu \mathrm{L} 10 \times$ PCR buffer (with $\mathrm{MgCl}_{2}$ ) and 1.5 U Taq polymerase (TaKaRa Biotechnology, China). PCR was performed in a MJ Research PTC-200 Thermal Cycler (BIO-RAD, USA) under the following reaction procedure: initial denaturation at $94^{\circ} \mathrm{C}$ for $5 \mathrm{~min}$, followed by 35 cycles of denaturation at $94^{\circ} \mathrm{C}$ for $1 \mathrm{~min}$, annealing at $\mathrm{X}^{\circ} \mathrm{C}$ for $45 \mathrm{sec}(\mathrm{X}$ was shown in Table 1) and extension at $72^{\circ} \mathrm{C}$ for $1 \mathrm{~min}$ with a final extension step at $72^{\circ} \mathrm{C}$ for $5 \mathrm{~min}$.

Then PCR products of each pair specific primer were pooled and sequenced, respectively. After compared the obtained sequences from Large White Landrace and Songliao Black pig, a G/T mutation was found in PCR amplification fragment of exon2 specific primers (Table 1). For individual genotyping, the PCR restriction fragment length polymorphism (PCR-RFLP) method was used to genotype the polymorphic sites. The PCR products were digested with $2 \mathrm{U} \mathrm{Fok}^{\circ} \mathrm{C}$ (TaKaRa Biotechnology, China) for at $37^{\circ} \mathrm{C}$ for $12 \mathrm{~h}$, respectively and analyzed on $5 \%$ agarose gels.

Association analysis: Considering the pedigree structure of three pig populations, association analysis between the genotypes of SNP and cytokine traits were examined by fitting the following mixed models using in SAS9.13 software:

$$
\mathrm{Y}=\mathrm{X} \beta+\mathrm{Zb}+\mathrm{e}
$$

Where:

$\mathrm{Y}=$ The vector of phenotype for cytokine traits analyzed

$\mathrm{X}=$ The design matrix for fixed effects

$\beta=$ The vector of fixed effects parameter including breed ELISA plate effect and genotype effect

$Z=$ The design matrix of random animal effects

$\mathrm{B}=$ The mixed vector of random component including sires effect and dam effect within sires

$\mathrm{E}=$ The vector of residual effect

Table 1: Specific primers used for SNP identification of the porcine IRF1 gene

\begin{tabular}{|c|c|c|c|}
\hline Fragments & Primers Sequence $\left(5^{\prime} \sim 3^{\prime}\right)$ & Product size (bp) & Annealing $\operatorname{Tm}\left(\mathrm{X}^{\circ} \mathrm{C}\right)$ \\
\hline IRF1-Exon 1 & GCTCTACAACAGCCTGATTTCC & 455 & 58.5 \\
\hline IRF1-Exon 2 & $\begin{array}{l}\text { GGTTTTCGGTCCCTACTTCCT } \\
\text { TCAAGGTGATAACAAGATTCGGAG } \\
\text { GTGGCAGAAAAACCCAAAAAGT }\end{array}$ & 307 & 59.6 \\
\hline IRF1-Exon 3 & $\begin{array}{l}\text { CATTCTCAGGATGGGTCAACTC } \\
\text { GTTGAAATGATGAACCCTCTCC }\end{array}$ & 428 & 60.2 \\
\hline IRF1-Exon 456 & $\begin{array}{l}\text { TGAGGCTTGCTGGATGTATTTG } \\
\text { CATCATCCTCCCCAGTCACAG }\end{array}$ & 833 & 60.2 \\
\hline IRF1-Exon 78 & $\begin{array}{l}\text { GGCAAACTAAGAAAGCACACAG } \\
\text { CCTCCCTTCCACAGTGTCTTT }\end{array}$ & 655 & 60.5 \\
\hline IRF1-Exon 9 & $\begin{array}{l}\text { TGATGCCTTCTTGTTTCTTTGT } \\
\text { GACCCAGATGAATGTCAAAAAG }\end{array}$ & 290 & 59.6 \\
\hline IRF1-Exon 10 & $\begin{array}{l}\text { CTATCCCCAGTCCTCACACA } \\
\text { GAAAACTCAAAACCTAACACTCC }\end{array}$ & 1299 & 60.2 \\
\hline
\end{tabular}




\section{RESULTS AND DISCUSSION}

SNP identification and genetic variation analysis: Sequence comparisons among three pig breeds revealed one SNP (GU201905:1367 G>T) in exon 2 of the porcine IRF1 gene and induced amino acid substitution, i.e., arginine to leucine. The SNP could be detected by restriction enzyme FokI, resulting in two fragment ( 61 and $246 \mathrm{bp}$ ) produced by allele $\mathrm{G}$ and two fragments (61 and $185 \mathrm{bp}$ ) produced by allele $\mathrm{T}$. The three band types were clearly obtained (Fig. 1).

A total of 284 DNA samples from animal population were genotyped and allele frequencies were determined for each breed (Table 2). Genetic variation analysis demonstrated that allele frequencies were not significantly different among three pig breeds. The allele $\mathrm{G}$ is obviously dominant in three detected breeds. In contrast, the allele $\mathrm{T}$ has lower frequencies and $\mathrm{TT}$ genotype is not detected in Large White and Songliao Black pig.

Association analysis of cytokine traits and the breed, SNP genotype: We performed an association study to determine whether the pig breed affected cytokines level. The detailed results (Table 3 ) showed that all the traits except ratio of IFN- to IL-10 (day 35) among the breeds were significantly different $(\mathrm{p}<0.05)$.

The IFN- $\gamma$ level (day 20; day 35) of Landrace were significantly higher than Large White and Songliao Black pig $(\mathrm{p}<0.01)$; On the other hand, Songliao Black pig had significantly higher $\amalg-10$ level (day 20; day 35 ) than Large White and Landrace $(\mathrm{p}<0.01)$; Ratio of IFN- $\gamma$ to IL-10 (day

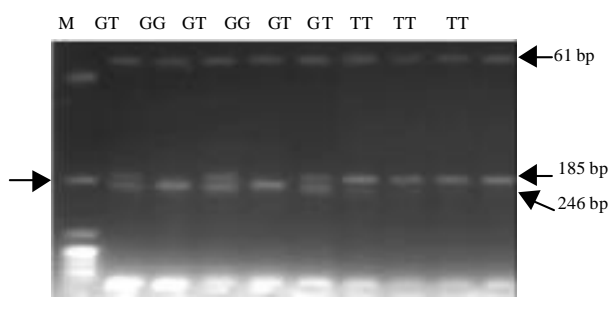

Fig. 1: PCR-FokI-RFLP analysis of the porcine IRF1 gene. Lane $\mathrm{M}$ is 100 bp DNA molecular weight marker; Lane GG, GT and TT represent different genotypes

Table 2: Genotype frequencies and allelic frequencies of the IRF1 gene determined by PCR-RFLP in three pig breeds

\begin{tabular}{lcrrrrr}
\hline & & \multicolumn{3}{c}{ Genotype frequencies } & \multicolumn{2}{c}{ Allele frequencies } \\
& Number & GG & GT & TT & G & T \\
Breed & 148 & 132 & 16 & 0 & 0.95 & 0.05 \\
Large white & 65 & 38 & 23 & 4 & 0.76 & 0.24 \\
Landrace & 71 & 57 & 14 & 0 & 0.90 & 0.10 \\
Songliao black & 71 &
\end{tabular}

20) of Songliao Black pig had significantly lower level than Large White and Landrace $(p<0.05)$. Association analysis results of cytokine traits and SNP genotype were shown in Table 4. The SNP of IRF1 gene had higher significant effect on level of IFN- $\gamma$ (day 20 ; day 35 ) in serum ( $p=0.0001 ; p=0.0001$ ) and ratio of IFN- $\gamma$ to IL10 (day 35) in serum $(p=0.0083)$. Further analysis results also showed that IFN- $\gamma$ level and ratio of IFN- $\gamma$ to IL10 in serum of pigs with TT genotype were significantly higher than those of pigs with a GG genotype $(\mathrm{p}<0.01)$.

The immune system plays an essential role in disease resistance of animals. The traits involved in the research are important parts of animal's immune capacity.

The ratio of IFN- $\gamma / \mathrm{IL}-10$ production reflects the capacity to activate or inhibit monocytic and $\mathrm{T}$ lymphocytic functions and a higher ratio has also been shown to be associated with depressive disorders (Maes, 1999).

The lower ratio of IFN- $\gamma$ to $\amalg-10$ of Songliao Black pig should be explained for Chinese indigenous breeds may have better $\mathrm{T}$ lymphocytic balance capacity than western commercial pig breeds. The results also implied that genetic background is one of the most important influences of cytokine traits. The genes affect the response of immune system could be researched as the candidate gene.

IRF1 participates with IFN- $\gamma$ in a series of autocrine loops that both induce and perpetuate the Th-1 response. In $\mathrm{T}$ cell, IFN- $\gamma$ induces IRF1 expression through the action of signal transducer and activator of transcription 1 (STAT1); IRF1 then influences IL-12, IL-4 and caspase 1 , leading to the generation of more FN- $\gamma$ (Pine et al., 1994; Coccia et al., 2000; Elser et al., 2002).

In human, the polymorphisms of IRF1 gene are revealed significant associated with asthma, Behcet's disease, hepatitis $\mathrm{B}$ virus infection, celiac disease and

Table 3: Association analysis of cytokines level in three pig breeds (Landrace, Large White and Songliao Black pig) Breeds (Least sequares mean \pm Standard error)

\begin{tabular}{|c|c|c|c|}
\hline Traits & $\begin{array}{l}\text { Large white } \\
(\mathrm{n}=148)\end{array}$ & $\begin{array}{l}\text { Landrace } \\
(\mathrm{n}=65)\end{array}$ & $\begin{array}{c}\text { Songliao black } \\
(\mathrm{n}=71)\end{array}$ \\
\hline IFN- $y$ (day 20) & $58.290 \pm 12.980^{\mathrm{A}}$ & $107.570 \pm 12.612^{\mathrm{B}}$ & $59.862 \pm 13.846^{A}$ \\
\hline IL-10 (day 20) & $81.815 \pm 42.491^{\mathrm{A}}$ & $133.620 \pm 41.286^{\mathrm{A}}$ & $173.740 \pm 45.324^{\mathrm{B}}$ \\
\hline $\begin{array}{l}\text { IFN- } \gamma \mathbb{L}^{-1}-10 \\
\text { (day 20) }\end{array}$ & $1.320 \pm 0.485^{\mathrm{a}}$ & $1.532 \pm 0.472^{\mathrm{a}}$ & $0.659 \pm 0.518^{b}$ \\
\hline IFN- $\gamma$ (day 35) & $59.528 \pm 16.095^{\mathrm{A}}$ & $100.470 \pm 15.639^{\mathrm{B}}$ & $66.501 \pm 17.168^{A}$ \\
\hline IL-10 (day 35) & $54.384 \pm 34.478^{\mathrm{a}}$ & $100.390 \pm 33.500^{\mathrm{ab}}$ & $107.210 \pm 36.777^{\circ}$ \\
\hline $\begin{array}{l}\text { IFN- } \gamma \mathbb{L}^{-1}-10 \\
\text { (day 35) }\end{array}$ & $1.907 \pm 0.462$ & $2.152 \pm 0.449$ & $1.648 \pm 0.493$ \\
\hline
\end{tabular}


Table 4: Association analy sis of the SNP genotypes of IRF1 gene with cytokine traits in three pig breeds Genotypes (Least sequares mean \pm Standard error)

\begin{tabular}{|c|c|c|c|c|}
\hline Traits & $\mathrm{GG}(\mathrm{n}=227)$ & GT $(n=53)$ & $\mathrm{TT}(\mathrm{n}=4)$ & p-value \\
\hline $\mathrm{IFN}-\gamma($ day 20$)$ & $28.506 \pm 4.368^{\mathrm{A}}$ & $95.021 \pm 8.463^{\mathrm{B}}$ & $102.200 \pm 34.683^{\mathrm{B}}$ & 0.0001 \\
\hline IL-10 (day 20$)$ & $152.380 \pm 14.298$ & $145.820 \pm 27.703$ & $90.980 \pm 113.540$ & 0.8570 \\
\hline $\mathrm{IFN}-\gamma \mathbb{L}^{-1}-10($ days 20$)$ & $0.850 \pm 0.163$ & $1.478 \pm 0.316$ & $1.183 \pm 1.297$ & 0.2158 \\
\hline $\mathrm{IFN}-\gamma($ day 35$)$ & $33.702 \pm 5.416^{\mathrm{A}}$ & $88.094 \pm 10.494^{\mathrm{B}}$ & $104.710 \pm 43.006^{\mathrm{B}}$ & 0.0001 \\
\hline IL-10 (day 35) & $119.140 \pm 11.602$ & $114.540 \pm 22.480$ & $28.296 \pm 92.125$ & 0.6222 \\
\hline IFN- $\gamma \mathbb{I L}^{-1}-10($ day 35$)$ & $0.888 \pm 0.155^{\mathrm{a}}$ & $1.836 \pm 0.301^{\mathrm{b}}$ & $2.983 \pm 1.234^{\mathrm{b}}$ & $0.0083^{\mathrm{ab}}$ \\
\hline
\end{tabular}

Signed by small letters differ significantly at $\mathrm{p}<0.05,{ }^{\mathrm{A} B}$ Means signed by capital letters differ significantly at $\mathrm{p}<0.01$

hepatitis C (Saito et al., 2002; Seegers et al., 2003; Cheong et al., 2006; Wang et al., 2006; Lee et al., 2007). The results also indicated that the SNP of IRF1 may be used as a genetic marker gene for cytokine traits with effects on IFN- $\gamma, \mathrm{IL}-10$ and ratio of IFN- $\gamma$ to IL-10 in serum. However, the polymorphism analyzed is functional mutation and may affect protein expression and regulation of gene for changing the phenotypes of traits. It is an interesting phenomenon of further biological functions investigation for genetic variation among other populations of pigs.

\section{CONCLUSION}

In this study, a SNP of the IRF1 gene was identified by PCR-RFLP and an association analysis was performed. The results showed that IRF1 gene was significant associated with cytokines level of 284 pigs from three different breeds. We also analyzed the cytokines level differences among three pig breeds. All these results will provide a foundation for further studies of the porcine IRF1 gene and may be helpful for application of disease resistance breeding in pigs.

\section{ACKNOWLEDGEMENTS}

This study is part of a research project supported by the National Key Project for Basic Research and Development Plans (Grant No. 2006CB102104) and National Science and Technology Support Plan (Grant No. 2008BADC1B02) of China.

\section{REFERENCES}

Akira, S., S. Uematsu and O. Takeuchi, 2006. Pathogen recognition and innate immunity. Cell, 124: 783-801.

Cheong, J.Y., S.W. Cho, S.G. Chung, J.A. Lee and M. Yeo et al., 2006. Genetic polymorphism of interferongamma, interferon-gamma receptor and interferon regulatory factor-1 genes in patients with hepatitis $B$ virus infection. Biochem. Genet., 44: 246-255.
Coccia, E.M., E. Stellacci, G. Marziali, G. Weiss and A. Battistini, 2000. FN- $\gamma$ and $\mathbb{L}-4$ differently regulate inducible NO synthase gene expression through IRF-1 modulation. Int. Immunol., 12: 977-985.

Elser, B., M. Lohoff, S. Kock, M. Giaisi, S. Kirchhoff, P.H. Krammer and M. Li-Weber, 2002. IFN- $\gamma$ represses IL-4 expression via IRF-1 and IRF-2. Immunity, 17: 703-712.

Lee, Y.J., S.W. Kang, J.K. Song, H.J. Baek and H.J. Choi et al., 2007. Associations between interferon regulatory factor-1 polymorphisms and Behcets disease. Human Immunol., 68: 770-778.

Lohoff, M. and T.W. Mak, 2005. Roles of interferonregulatory factors in T-Helper-cell differentiation. Nat. Rev. Immunol., 5: 125-135.

Maes, M., 1999. Major depression and activation of the inflammatory response system. Adv. Exp. Med. Biol., 461: 25-46.

Miyamoto, M., T. Fujita, Y. Kimura, M. Maruyama and H. Harada et al., 1988. Regulated expression of a gene encoding a nuclear factor, IRF-1, that specifically binds to IFN-beta gene regulatory elements. Cell, 54: 903-913.

Nguyen. H., J. Hiscott and P.M. Pitha, 1997. The growing family of interferon regulatory factors. Cytokine Growth Factor Rev., 8: 293-312.

Pine, R., A. Canova and C. Schindler, 1994. Tyrosine phosphorylated p91 binds to a single element in the ISGF2/IRF-1 promoter to mediate induction by IFN- $\alpha$ and IFN- $\gamma$ and is likely to autoregulate the p91 gene. EMBO J., 13: 158-167.

Redpath, S., A. Angulo, N.R.J. Gascoigne and P. Ghazal, 1999. Murine cytomegalovirus Infection downregulates $\mathrm{MHC}$ class II expression on macrophages by induction of IL-10. J. Immunol., 162: 6701-6707.

Saito, H., S. Tada, K. Wakabayashi, N. Nakamoto and M. Takahashi et al., 2002. The detection of IRF-1 promoter polymorphisms and their possible contribution to $\mathrm{T}$ helper 1 response in chronic hepatitis C. J. Interferon Cytokine Res., 22: 693-700.

Sambrook, J., E.F. Fritsch and T. Maniatis, 1989. Molecular Cloning: A Laboratory Manual. 2nd Edn., Cold Spring Harbor Laboratory Press, New York. 
Schoenborn, J.R. and C.B. Wilson, 2007. Regulation of interferon-gamma during innate and adaptive immune responses. Adv. Immunol., 96: 41-101.

Seegers, D., M.E. Borm, M.J. van Belzen, C.J. Mulder and J. Bailing et al., 2003. IL12B and IRF1 gene polymorphisms and susceptibility to celiac disease. Europ. J. Immunogenet., 30: $421-425$.
Taniguchi, T., H. Harada and M. Lamphier, 1995. Regulation of the interferon system and cell growth by the IRF transcription factors. J. Cancer Res. Clin. Oncol., 121: 516-520.

Wang, T.N., Y.T. Chu, W.Y. Chen, W.W. Feng, N.H. Shih, C.H. Hsiang and Y.C. Ko, 2006. Association of interferon-gamma and interferon regulatory factor 1 polymorphisms with asthma in a family-based association study in Taiwan. Clin. Exp. Allergy, 36: 1147-1152. 